\title{
The Performance of Production, Price and Marketing System of Shallot in Central Java
}

\author{
Seno Basuki, Munir Eti Wulanjari, Komalawati and Dewi Sahara* \\ Central Java Assessment Institute for Agricultural Technology, Indonesia
}

\begin{abstract}
Shallots are one of the horticultural products that have important economic values. The objective of this study is to analyse the performance of production and price as well as to identify the marketing system of shallot. The research used time-series data from 2009 to 2018. The data was analyzed descriptively. The results showed that the harvested area and production of shallot have an increasing trend, while the productivity of shallots has a decreasing trend during the last 10 years (2009 to 2018). The price of shallots has been fluctuating from 2009 to 2018. The fluctuation of shallots price was caused by the fluctuation of production. The distribution of shallots from production centres to end consumers requires marketing services carried out by marketing agents. The shallot marketing channel involves two or more market players. The longer the marketing channel, the higher the marketing margin, and the lower the share of the price would be received by farmers (profit sharing). Conversely, the shorter the marketing channel, the lower the marketing margin and the higher the share of farmers would be. Therefore, to increase farmer share, there should be an institution that could facilitate a shorter marketing margin between farmers and consumers.
\end{abstract}

\section{Introduction}

Shallots are a horticultural product that is used by every household as a cooking spice [1]. Apart from being used by households, shallots are also used as raw materials for food processing industries. Align with the development of food industry and the increase in the number of population, demand for shallots continues to increase from year to year.

As other agricultural commodities, shallots are easily damaged due to physical, mechanical, and biological influences. These characteristics of shallot have caused the price of shallots to fluctuate frequently [2,3]. Apart from shallot durability, fluctuations in the price of shallots are also caused by fluctuations in production due to seasonal factors. Furthermore, the production areas are centralized at certain areas, while the consumption areas are scattered throughout the region [4]. Therefore, shallots are sometimes difficult to find in a region but are available abundance in another area. In other words, shallots are not distributed according to its demand. Therefore, shallots need to be distributed to every point of consumption through several marketing channels that connect producers (farmers) and consumers across rural and urban areas.

Central Java is a national shallot productions centres with its production centres in Brebes District. The marketing of shallots is not only in or between cities/regencies but also

\footnotetext{
*Corresponding author: dewisahara.ds@gmail.com
} 
between islands and even between countries (export market). [5] stated that the price of shallots could be a signal of a balance between supply and demand. Wider consumer areas means the marketing of shallots involve not only farmers and consumers but also various marketing institutions [6].

The distribution of shallots by marketing agencies through several activities, starting from purchasing and collecting from producer farmers, and then sorting, keeping in the storage, packaging, and distributing. At every stage of marketing activities, additional costs are required, and thus, the price paid by consumers would be different from the price received by farmers. Therefore, this study aims to determine the production performance and price fluctuations as well as the marketing of shallots in Central Java.

\section{Research Methods}

The study used time-series data from 2009 to 2018, namely data on harvested area, production, and productivity, as well as average monthly producer prices, consumer prices, and retail prices. Data obtained from the Central Bureau of Statistics and the Ministry of Trade. The data obtained were analysed by simple statistics and descriptive analysis. Descriptive analysis is used to analyse data by describing the actual data that has been collected without intending to make conclusions that apply to society or generalizations. The simple descriptive and statistical analyses are aimed to transform a set of raw data into another form of concise information.

\section{Result and discussions}

\subsection{Development of Harvested Area, Production and Productivity of Shallots}

Shallots are one of the leading horticultural commodities in Central Java which have good development prospects. In the period of 2009 to 2018, shallots have been planted in almost all regions of Central Java ( 29 districts and one city). The widespread of shallot plantation could be seen by the increasing harvested area by 8,036 ha from 38,280 ha in 2009 to 46,316 ha in 2018 (Table 1). The increasing harvested areas is reasonable since shallots could be cultivated in the lowlands (an altitude of 1,000 meters above sea level), and could grow optimally at an altitude of 0 to $450 \mathrm{~m}$.

Table 1. The performance of shallot development in Central Java, 2009 to 2018

\begin{tabular}{|c|c|c|c|c|}
\hline No & Year & Harvest Area (ha) & Production (ton) & Productivity (ton/ha) \\
\hline 1. & 2009 & 38,280 & 406,725 & 10.63 \\
\hline 2. & 2010 & 45,538 & 506,357 & 11.12 \\
\hline 3. & 2011 & 35,711 & 372,256 & 10.42 \\
\hline 4. & 2012 & 35,828 & 381,814 & 10.66 \\
\hline 5. & 2013 & 36,715 & 419,472 & 11.43 \\
\hline 6. & 2014 & 46,233 & 519,356 & 11.23 \\
\hline 7. & 2015 & 42,631 & 471,169 & 11.05 \\
\hline 8. & 2016 & 53,331 & 546,686 & 10.25 \\
\hline 9. & 2017 & 51,155 & 476,337 & 9.31 \\
\hline 10. & 2018 & 46,316 & 445,585 & 9.62 \\
\hline & $\begin{array}{l}\text { Average } \\
\text { (\%/year) }\end{array}$ & 3.20 & 1.91 & -1.29 \\
\hline
\end{tabular}

Source: [7] 
In general, the harvested area of shallot in Central Java fluctuates with an increasing trend. A significant increase in the harvested area occurred from 36,715 ha in 2013 to 46,233 ha in 2014 or increased by 9,519 ha $(20.59 \%)$. In the following years, the harvested areas fluctuate from 2016 to 2018. Although the harvested area of shallots were fluctuated, it still showed a positive trend with an average increase of $3.20 \% / y e a r$. The growth of harvested areas of shallot is presented in Figure 1.

The development pattern of shallot production follows the development pattern of the harvest area which has increased from 406,725 tonnes in 2009 to 445,585 tonnes in 2018, however, in 2011 shallot production has decreased by 134,101 tonnes compared to 2010 . The highest production was obtained in 2016 amounting to become 546,686 tons, after which production fell again. Production development fluctuates due to weather changes. As stated by [8], the increase in onion production in Karnataka is due to fluctuating area changes due to the risk of weather causing instability of production. Even so, the development of shallot production in Central Java for the 2009 to 2018 period showed a positive trend with an average increase of $1.91 \% /$ year (Figure 2).

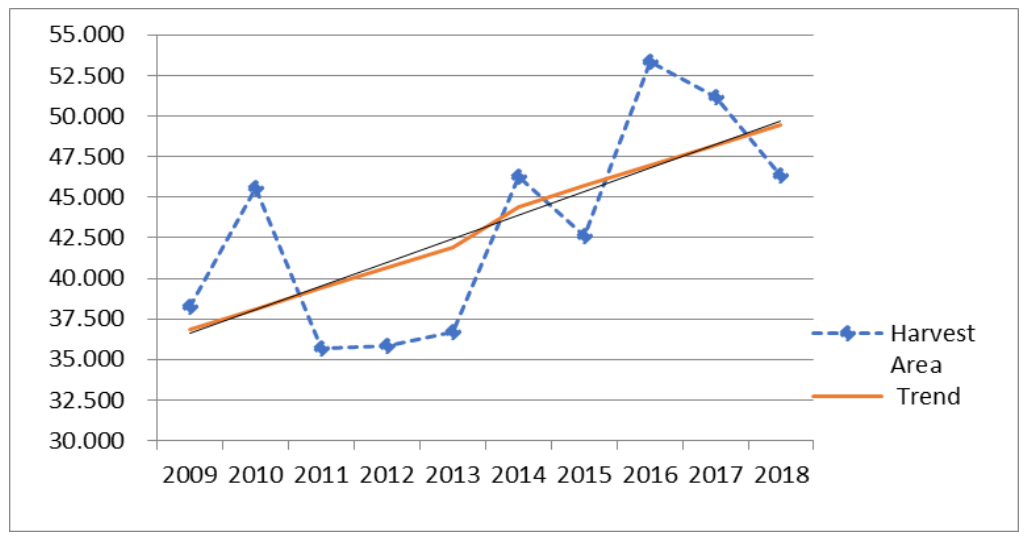

Source: [7]

Fig. 1. Development Trend of Shallot Harvest Area in Central Java, 2009 to 2018

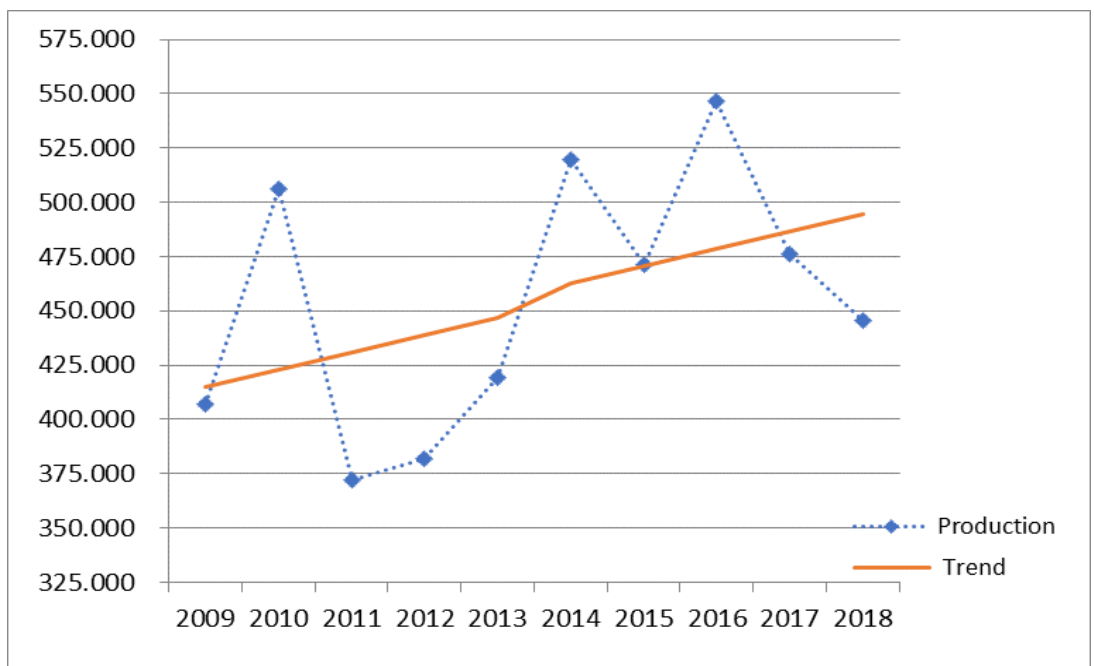

Source: [7]

Fig. 2. The Growth of Shallot Production in Central Java, 2009 to 2018 
In contrast to the growth trend of harvested and production areas, the growth of shallot productivity from 2009 to 2018 period showed a negative growth around $1.29 \%$ /year on average (Figure 3). These data indicate that the increasing rate of shallot production is driven by the increasing of harvested area than productivity. Therefore, technological innovation is important to increase the productivity of shallots.

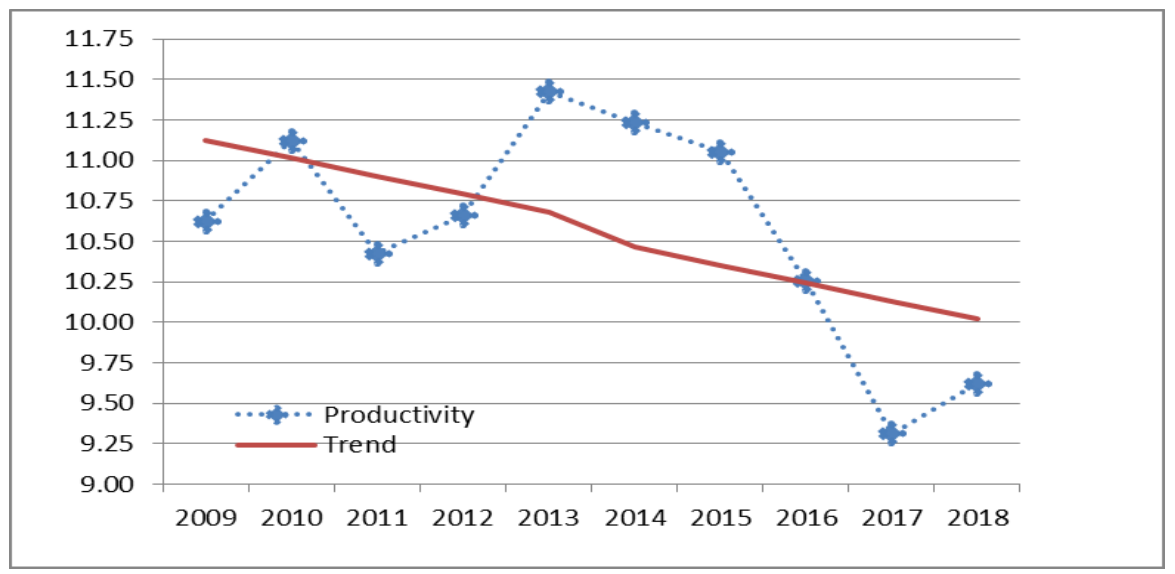

Source: [7]

Fig. 3. Development Trend of Shallot Productivity in Central Java, 2009 to 2018

Farmers still use conventional technology and hesitant to adopt a whole technological innovations for technical, social, and capital reasons. The difficulty of farmers to adopt technological innovation could be one of reasons for decreasing shallot productivity. According to [9], farmers have to face various obstacles, both technical and economic constraints in the shallot production process. These obstacles include the unavailability of shallot seeds with high-yielding quality in the appropriate time and the quantity required by farmers.

In addition to the availability of seeds, most farmers still use seed bulbs for shallot farming compared to True Shallot Seed (TSS). The high price of seed bulbs has led farmers to use some of their harvested shallot to be planted in the following season. [10] stated that the utilization of seeds from previous harvest would affect the optimalization of productivity, yield quality, and farming efficiency since those seeds were not planted for seeds. [1] argued that the application of appropriate technology has a contribution to increasing crop yields.

\subsection{Price Movement of Shallot}

Shallot prices in Central Java in the last 10 years (2009 to 2018) tends to fluctuate. Price fluctuations are indicated by the movement of price with increasing and decreasing pattern in certain years at the producer, rural consumer, and retail prices (Table 2).

The price of shallots at the producer level is more fluctuate than the price at the rural consumer and the retail level. [14] has shown similar results. According to [14], the price of shallots in the producer market tends to be very low and fluctuate compared to the price in the consumer market. High fluctuations in the price of shallots can disrupt the continuity of farmers in production [15] since high fluctuation could indicate high uncertainty in selling price received and thus, could affect the quantity of production. During the last 10 years, the price of shallots at the producer level has tended to be stable from 2009 to 2013 which was in the range of IDR $6,675 / \mathrm{kg}$ to IDR $7,395 / \mathrm{kg}$. In 2014 , the price jumped sharply with an increase of $49.79 \%$ from 2013. After 2014, there were a decreasing price in 2015 
and 2016, before the price was sharply increased in 2017 with an average of IDR 19,450/kg and the prices in 2017 were the highest prices during that period. Overall, the growth of shallot prices at the producer level was $11.23 \%$ /year.

Table 2. Average Trend of Shallot Prices in Central Java, 2009 -2018

\begin{tabular}{|c|c|c|c|c|}
\hline \multirow{2}{*}{ No. } & \multirow{2}{*}{ Year } & \multicolumn{3}{|c|}{ Price at Level (IDR/kg) $^{2}$} \\
\cline { 3 - 5 } & & Producers $^{1}$ & Rural Consumers $^{2}$ & Retail $^{3)}$ \\
\hline 1. & 2009 & 6,843 & 8,804 & 14,050 \\
\hline 2. & 2010 & 6,676 & 13,255 & 17,068 \\
\hline 3. & 2011 & 7,396 & 20,942 & 18,955 \\
\hline 4. & 2012 & 7,390 & 23,173 & 14,177 \\
\hline 5. & 2013 & 7,385 & 25,403 & 34,448 \\
\hline 6. & 2014 & 11,062 & 17,392 & 22,635 \\
\hline 7. & 2015 & 9,687 & 16,477 & 25,260 \\
\hline 8. & 2016 & 9,454 & 18,226 & 39,233 \\
\hline 9. & 2017 & 19,450 & 24,886 & 27,738 \\
\hline 10. & 2018 & 17,262 & 20796 & 24,208 \\
\hline & $\begin{array}{l}\text { Growth } \\
\text { (\%/years) }\end{array}$ & 11.23 & 7.44 & 8.03 \\
\hline & CV (\%) & 44.86 & 31.27 & 35.11 \\
\hline
\end{tabular}

Sources : ${ }^{1)}[11$, processed $] ;{ }^{2}[12$, processed $] ;{ }^{3)}[13$, processed]

The high fluctuation of shallot price at the producer level is caused by the seasonal production of shallots throughout the year [16]. Farmers produce shallot only once a while and they do not have storage to keep the shallots and sell it during off-season period. Storing shallots without special handling in conventional warehouses could cause weight loss between 30 and 50\%. Additionally, shallots are easily damaged (grow roots/shoots and rot) and thus, farmers would not delay for selling their shallot production after harvested.

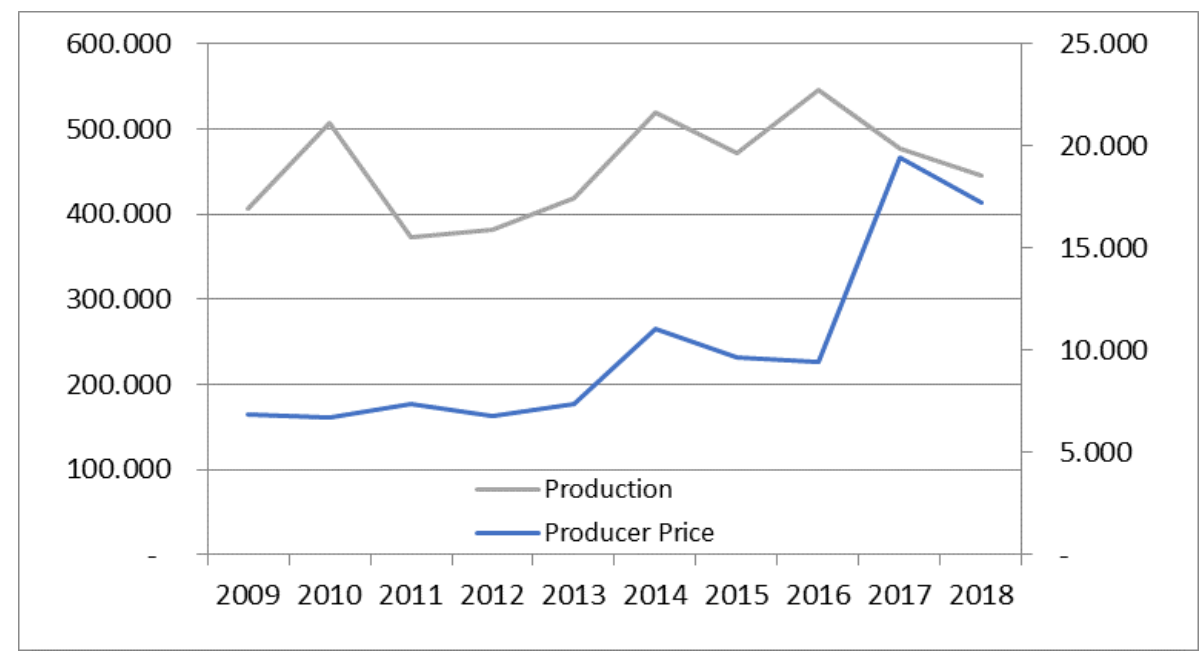

Source: $[7 ; 11]$

Fig. 4. The Price Movement of Shallots at the Producer Level and Growth of Shallot Production in Central Java, 2009 to 2018

The trend of shallot prices at the producer level tends to follow the growth of production in different direction. If the production increases, the price of shallots will fall, and vice 
versa. Different direction of production and price is supported by [8] that explains the fluctuation of prices that are related to production. As an example, the highest production of shallots was obtained in 2016 (546,686 tons), and at the same year, the price was lower than the previous year which was IDR $9,454 / \mathrm{kg}$. High fluctuations of shallot prices in producer level started in 2013 and reached its peak in 2017. The greater the amount of shallot production produced by farmers, the lower the prices of shallots is at the producer level. [2; 7] argued that production fluctuations was the cause for price fluctuations at the producer level. The relationship between price movement and the growth of production is presented in Figure 4.

The average price of shallots at the consumer level in rural areas during the period of 2009 to 2018 ranged from IDR 8,804/ka to IDR 25,403/ kg. The lowest price of shallots was obtained in 2009, and the highest was in 2013. After 2013, the price of shallots continue to decrease until 2018. However, in general, the price of shallots at the consumer level in rural areas has increased with an average growth of $7,44 \% /$ year.

The retail price of shallots is the price at the distributor level such as groceries, market traders that are spread across all districts/cities in Central Java. The prices of shallots show a positive trend for 10 years with an average increase around $35.11 \%$ /year. The lowest retail price was obtained in 2009 (IDR $14,050 / \mathrm{kg}$ ) and the highest price was IDR 39,233/kg in 2016. The fluctuation of price shallots at the retail level is not as high as in the producer level, but higher compared to the price fluctuations at the consumer level in rural areas. Different fluctuation pattern between prices at the farmers, retailer, and consumer level could indicate the existence of asymmetric price transmission. [17] through their study on asymmetric price transmission in shallot marketing chain found an asymmetric price transmission in the short run between farmers and groceries and in the long run between groceries and retailers. [17] found an indication of market power abused by one of the distributors along the marketing chain of shallot from Brebes to Jakarta. These market power abused are possible since there are a longer distribution channel of market shallots from production to consumption centers. As $[18 ; 19]$ argued, price fluctuations can be triggered by product availability in the market and marketing chain, as well as an imbalance between supply and demand.

According to Table 2, the coefficient of variation $(\mathrm{CV})$ of shallot price at the producer level is the highest compared to that at the consumer level. This means the price of shallots in the producer market is more fluctuating than that at the consumer level. The price of shallots at the consumer level in rural areas is more stable than prices of shallots at retail level. A study by [20] in Nganjuk district found that demand and supply of shallots in the consumer market were relatively more stable which could be seen from the lower CV value of the price of shallots in the consumer market $(50.16 \%)$ compared to that of the producer market (59.32\%). Another study by [21] showed a higher CV value of shallot for farmers (8.70\%) compared to the CV of shallot prices at the consumer level $(7.66 \%)$ in Sri Lanka was an indication of higher fluctuation of prices at the farmer level compared to that of the retail price, and farmers in Sri Lanka have to face a low profit and high-risk market of shallots. Those studies explained that the stable price at the consumer level are due to the relatively stable demand and supply of shallots compared to the conditions at the farmer/producer level.

\subsection{Shallot Marketing}

\subsubsection{Shallot Marketing Channels}

Marketing is a process of delivering an item from one production center to several consumption center points. The production for agricultural commodities are centralized in 
rural areas, while the consumption centers are scattered in several rural and urban areas. Marketing services are used to deliver products from production to consumption centers. [22] defined a supply chain in marketing system as activities from production to distribution of agricultural products from production centers to end consumers. These activities, marketing has an important meaning in the distribution process of agricultural products by considering the benefits for the marketing actors. [23; 24] argued that a good marketing system will support producers to increase their production and distribute agricultural products on time [25].

The distribution of shallot products from farmers to final consumers generally involves three marketing actors, namely producers, marketing institutions, and consumers [26; 27]. [14] differentiate marketing actors between producer and consumer market. Producer market actors are farmers, collectors, and wholesalers, while consumer market actors are retailers and households.

The marketing system involved various actors from region to region depending on the targets to be achieved, namely between villages, between sub-districts/districts, or export markets. Every market chain has different marketing channel. [28] argued that in Kampar District, Pekanbaru, there are two marketing channels for shallots, namely: farmers collectors - retailers - consumers, and farmers - wholesalers - collectors - retailers consumers. The shallot marketing chain in Majalengka Regency involves eight marketing actors, namely farmers, dealers, middleman, farmer groups, partner institutions, modern markets, local markets, and wholesale markets, and thus, they have identified 6 different marketing channels, namely: 1) farmers - local retailers - consumers; 2) farmers - farmer groups - partners - modern markets - consumers; 3) farmers - a middleman - local markets - consumers; 4) farmers - a middleman - wholesale market dealers - consumers; 5) farmers - wholesalers - local markets - consumers; and 6) farmers - airport - wholesale market consumers [23].

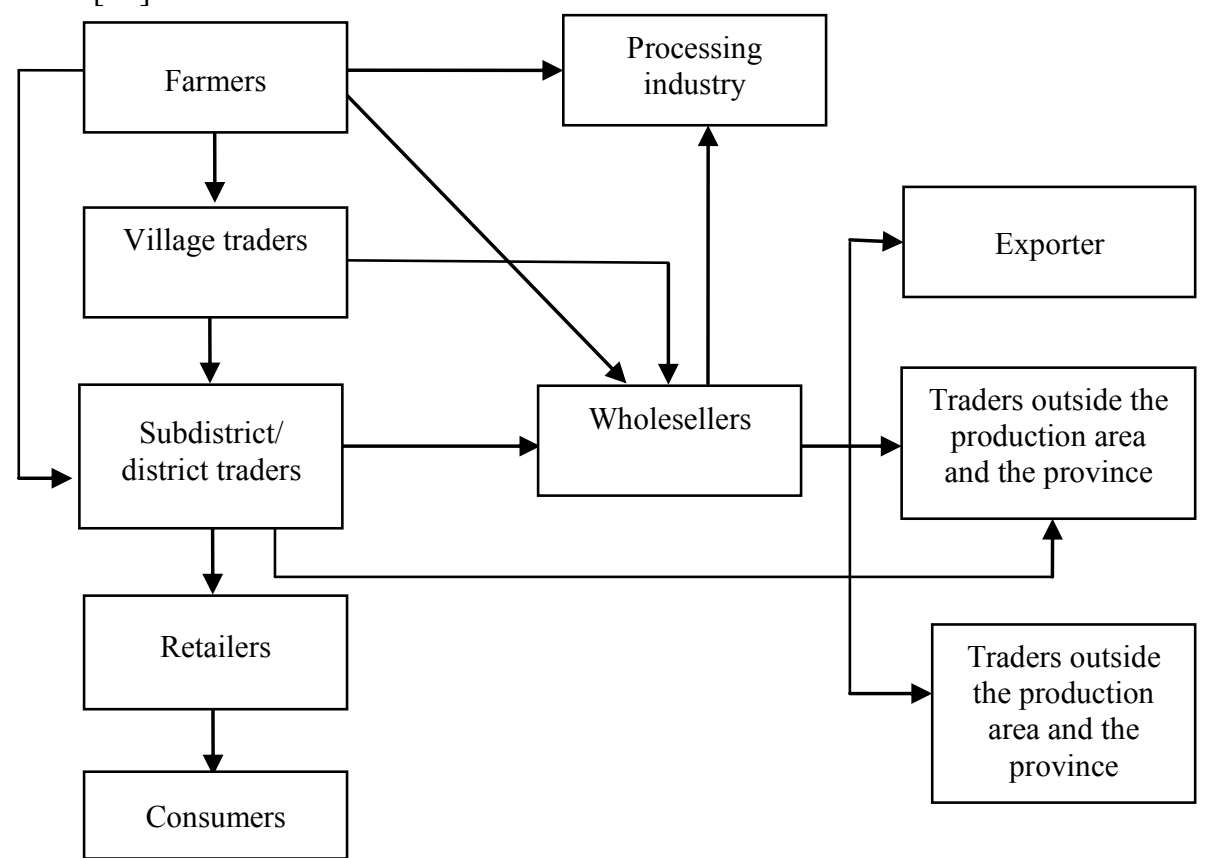

Sources: $[30 ; 31]$

Fig. 5. Marketing Channels of Shallots in Central Java 
Central Java is one of the centers of shallot production in Indonesia with its production centers in Brebes Regency. There are several marketing channels, namely local shallot marketing, inter-island shallot marketing, and shallot marketing for export activities [29; $30 ; 31]$. In general, the marketing of shallots in Central Java is shown in Figure 5.

In general, the marketing chain in shallot is started from the farmer level. Farmer sell shallots to village traders who collect shallots at the village level. village-level collectors would sell their shallots to the traders at the subdistrict/district level and then distributed them to wholesalers. Wholesalers would have a wider marketing areas. The wholesalers could sell the products to other cities or region outside the production area (regencies, provinces, islands), the main market in the cities, processing industries, or exporters. The wholesalers could sell their products to wider areas since they have easier access, both access to capital, information and networks that the local/district traders do not have. Traders (including wholesalers and collectors) play a dominant role in the distribution of product compared to farmers $[32 ; 33]$. This is because traders have a wider range of information with easier access to capital and networks. Therefore traders have the power to control the input and output markets compared to farmers, and they could could the whole process of marketing system from purchasing, sorting, storing, distributing/transporting the products, managing the risk and selling to the consumer.

Another marketing chain in the production center is farmers sell directly shallot to subdistrict/district traders, and the sub-district/regency traders would sell it to retailers in the markets until it finally reaches the consumers. Some farmers in Brebes District, especially farmers who have a medium and high scale production, would create partnerships with processing industries. The farmers would supply raw materials (shallots) with a certain quantity and quality in a long term. Therefore, the partner industries would ensure the continuity of the products. This continuity in the product quantity and quality sometimes have become the obstacles for farmers to become the partners, and thus, the partnership could not involve every farmer in the location.

\subsubsection{Shallot Marketing Efficiency}

The efficiency of shallot marketing can be seen from the marketing channels that involve several marketing actors/agencies. Difference marketing channel would lead to difference price received by producers and paid by consumers. A longer marketing chain would cause a low price received by farmers and a higher price paid by consumer. In other words, a longer marketing chain would cause a higher marketing margin. The gap between producer and consumer prices could be caused by a lack of market information (price, supply, and demand), rural infrastructure, mobilization for marketing actors, especially for farmers [34; $35 ; 36]$. An ineffective market would give an impact on the profits obtained by marketing agencies and farmers. Farmers and marketing actors would receive smaller profits since there are many costs to market shallots until it reaches consumers. The marketing chain would also determine the profit margin of each market actors received.

Most of the farmers sell shallot products to collector traders at the village level and this will subsequently affect the profits they get. Wholesalers rarely buy shallots directly from farmers because they only produce in small quantity. The wholesalers prefer to buy from the collectors with large quantity. This creates a multi-layered supply chain, resulting an inefficient markets for farmers. [36] argued that the involvement of several intermediary traders in the traditional vegetable market causes very large price differences between producers and consumers, resulting in marketing inefficiency.

The longer the marketing channel, the more marketing agencies enjoy profit margins and create an inefficiency in the marketing system [37]. [33] stated that the lack of market 
information could cause disintegration between the producer market and wholesale and retail markets in the short term. This shows the inefficiency of shallot supply chain system.

\subsubsection{Marketing Margin}

The marketing system for agricultural commodities simply consists of two types of markets, namely the producer and the consumer market. The delivery of goods from the producer to the consumer requires transaction costs such as transportation cost, packaging and others. Therefore, there are differences in prices at the producer and the consumer level. The differences in price paid by consumers and received by the producer is defined as the marketing margin.

Differences between prices along the marketing channels due to the additional costs and profits of each marketing actor. Research by [37] found that the marketing margin of shallots in Ambon City was IDR 2,900/kg. The marketing margin consisted of $27.72 \%$ for marketing and the remaining $72.28 \%$ for profit of the agency. The ratio of the profit margin to the marketing costs of shallots in Brebes Regency is between 0.82 to 9.81 [30]. Some results of these studies indicate that the high price of shallots at the consumer level is due to the high profits in each marketing agency. Therefore, to increase profits at the producer level, farmers should sell shallots directly to consumers. [38] suggest that if farmers are able to shorten the marketing channels, they will earn higher income/profits from the crops sold in the market.

The marketing costs needed to distribute shallots from producers to consumers include labor costs for cleaning, packaging, selection, loading, unloading, and transportation. Furthermore, there are also depreciation and transportation costs [30]. By using the data in Table 2, the marketing margin of shallot are calculated and presented in Table 3.

Table 3. Shallot Marketing Margin in Central Java, 2009 to 2018

\begin{tabular}{|c|c|c|c|c|c|}
\hline \multirow{2}{*}{ No } & \multirow{2}{*}{ Years } & \multicolumn{4}{|c|}{ Marketing Margin } \\
\cline { 3 - 6 } & & \multicolumn{2}{|c|}{ Rural Area } & \multicolumn{2}{c|}{ Retail } \\
\cline { 3 - 6 } & & Value (IDR) & Share (\%) & Value (IDR) & Share (\%) \\
\hline 1. & 2009 & 1,961 & 22.27 & 7,207 & 51.30 \\
\hline 2. & 2010 & 6,579 & 49.63 & 10,392 & 60.89 \\
\hline 3. & 2011 & 13,546 & 64.69 & 11,559 & 60.98 \\
\hline 4. & 2012 & 4,270 & 38.71 & 7,418 & 52.32 \\
\hline 5. & 2013 & 18,018 & 70.93 & 27,063 & 78.56 \\
\hline 6. & 2014 & 6,330 & 36.40 & 11,573 & 51.13 \\
\hline 7. & 2015 & 6,790 & 41.21 & 15,573 & 61.65 \\
\hline 8. & 2016 & 8,772 & 48.13 & 29,779 & 75.90 \\
\hline 9. & 2017 & 5,436 & 21.85 & 8,288 & 29.88 \\
\hline 10. & 2018 & 3,534 & 16.99 & 6,946 & 28.69 \\
\hline & Average & & 41.08 & & 55.13 \\
\hline
\end{tabular}

Sources : ${ }^{1)}[11$, processed $] ;{ }^{2)}[12$, processed $] ;{ }^{3)}[13$, processed]

The percentage of shallot marketing margin in rural areas is lower than the marketing margin at the retail level. The lower marketing margin in the rural areas comes from the shorter marketing channel. They sell shallot between villages. The marketing channel involves only two or three marketing actors, namely farmers to consumers or farmers, new village-level collectors to consumers. Higher marketing margins are obtained in markets that have longer channels. The price of shallots at the rural consumer-level only exceeds one or two intermediary traders, while urban consumers (retail prices) the price of shallots 
goes through more than 2 intermediary traders, where each intermediary trader gets to profit from marketing activities.

As research by [27] found that a longer marketing channel has a higher marketing margin. The higher the marketing margin, the more inefficient the market would be. A higher marketing margin could be seen from a higher price gap between the price at the producer level and the price at the consumer. [30] also found that the marketing margin of shallots outside Java Island is higher than the marketing margin of shallots in Java. This higher marketing margin for shallots in other islands is caused by higher transportation cost from Java to the islands.

\subsubsection{Farmer Share}

The portion of the price received by farmers (farmer share) is an approach to identify the amount of compensation received by farmers from the products produced. The shorter the marketing channel, the greater the share of the price is received by farmers. The shorter marketing channels are beneficial for farmers since they could obtain an adequate proportion of profits and compensation for mitigating the agricultural risks. By using the data in Table 2, the farmer share of shallot received by farmers in Central Java could be seen in Table 4.

The lowest average farmer share of shallot marketing was obtained from the shallot marketing channel to the consumer level which is spread throughout Central Java Province $(44.87 \%)$ and the highest farmer share was obtained in shallot marketing at the consumer level in rural areas $(58.90 \%)$. A study by [35] showed that the price share received by farmers is $40 \%$ of the retail price. According to these results, the share of the price received by farmers are between $40-60 \%$ of the price paid by consumers. [33] argued that one of the determinants of the share of farmer prices is the distribution chain of products and services in the market, the longer the marketing channel, the greater the marketing margin so that the share of prices received by farmers is getting smaller [39]. According to the results obtained, it shows that marketing margin with farmer share has a negative relationship, meaning that high marketing margin will have an impact on low farmer share.

Table 4. Farmer Share in Shallot Marketing in Central Java, 2009 to 2018

\begin{tabular}{|c|c|c|c|}
\hline \multirow{2}{*}{ No } & \multirow{2}{*}{ Years } & \multicolumn{2}{|c|}{ Farmer Share (\%) } \\
\cline { 2 - 4 } & & Rural & Retail \\
\hline 1. & 2009 & 77.73 & 48.70 \\
\hline 2. & 2010 & 50,37 & 39,11 \\
\hline 3. & 2011 & 35.31 & 39.02 \\
\hline 4. & 2012 & 61.29 & 47.68 \\
\hline 5. & 2013 & 29.07 & 21.44 \\
\hline 6. & 2014 & 63.60 & 48.87 \\
\hline 7. & 2015 & 58.79 & 38.35 \\
\hline 8. & 2016 & 51.87 & 24.10 \\
\hline 9. & 2017 & 78.15 & 70.12 \\
\hline 10. & 2018 & 83.01 & 71.31 \\
\hline & Average & 58.90 & 44.87 \\
\hline
\end{tabular}

Sources : ${ }^{1)}\left[11\right.$, processed]; ${ }^{2)}\left[12\right.$, processed]; ${ }^{3)}[13$, processed]

Farmer share for shallot marketing in rural areas varies between $29.07 \%$ to $83.01 \%$, while the lowest in other markets is $21.44 \%$ to $71.31 \%$. The lowest farmer share in both markets occurred in 2013 since there was a sharp increase in prices at the consumer level to more than $100 \%$, while prices at the farmer level only increased $9.26 \%$. Therefore, the 
share of prices received by farmers became lower. In that year, the biggest marketing margins were $70.93 \%$ and $78.56 \%$, respectively in the rural market and other markets. According to these two indicators, it indicates that the changes in the price increased of shallots at the producer level is lower than the changes in the price increased at the consumer level.

A market that has a higher marketing margin involves many marketing actors. Every actor along the marketing channels set the prices by considering the marketing costs and the profit. Therefore, the proportion of the price paid by consumers and the price received by producers is lower. By comparing the value of the marketing margin and farmer share in the rural market and other shallot markets in Central Java, the rural shallot market tends to be more efficient than other markets. Marketing channels with lower marketing margins and the largest farmer shares are efficient marketing channels. On the other hand, if the marketing channels have higher marketing margins and small farmer shares, the marketing channels are less efficient.

\section{Conclusion}

The fluctuations of shallot prices in Central Java have a different direction with the fluctuations in its production. The price of shallots decrease when production increases and vice versa. In 2009 - 2018 period, there were an increase in the production due to the expansion of the planted area.

There are several shallot marketing channels in Central Java, depending on the marketing goals and objectives. The longer the marketing channel, there are more marketing actors/agencies involved and thus, the shallot market would be less efficient. This less efficient market is due to higher marketing margin and lower share of the price received by farmers (farmer share). On the other hand, a shorter marketing channel would lower the marketing margin and increase farmer share. Therefore, to increase farmer share, there should be an institution that could facilitate a shorter marketing channel between farmers and consumers. This institution could be in the form of cooperatives or the village companies that could buy farmers' product and sell it directly to groceries or retail markets or consumers. Another way of shortening the marketing channel is by utilizing the internet of things to sell directly to the consumers. However, farmers need to be trained, and thus, this alternative requires a longer time.

\section{References}

1. G. Gebretsadkan, Y. Gebremicael, K. Asgele, E. Abebe, W. Gebrelibanos, and Y. Tsehaye. Int. J. Environ. Agric. Biotechnol. 3, 3 (2018)

2. H. R. Kasim, C. E. Atmisari, and M. Lutfi. Pinisi Discret. Rev. 3, 1 (2019)

3. D. Tulipa, D. Rachmawati, L. Ellitan, and I. Srianta. Food Res. 4, 2 (2020)

4. Susanawati. Adv. Eng. Res. 194 (2020)

5. R. Asmara and R. Ardhiani. J. Agrise. 10, 3 (2010)

6. H. A. Eka, P. I. Ilmi, and P. D. Ellingga. Russ. J. Agric. Socio-Economic Sci. 6, 66 (2017)

7. Badan Pusat Statistik Proinsi Jawa Tengah. (2010-2018)

8. G. Basavaraj, M. Nandikoppa, H. M. Swamy, and A. S. Alur. J. Farm Sci. 32, 4 (2019)

9. G. Wiguna, I. M. Hidayat, and C. Azmi. J. Hortik. 23, 2 (2013)

10. I. M. Mariawan, I. S. Madauna, and Adrianton. e-J. Agrotekbis. 3, 2 (2015) 
11. Badan Pusat Statistik Indonesia. (2010-2019).

12. Badan Pusat Statistik Indonesia. (2010-2018)

13. Ministry of Trade. (2010)

14. S. Sholihah and Karsinah. Econ. Dev. Anal. J. 8, 4 (2019)

15. M. I. Riyadh. J. Ekon. Kebijak. Publik. 9, 2 (2018)

16. D. Nuraeni, R. Anindita, and Syafrial. Habitat. 26, 3 (2015)

17. J. A. Ruslan, M. Firdaus, and Suharno, Bul.Ilm. Litbang Perdagang. 10, 1 (2016)

18. H. Xie and B. Wang. Sustainability. 9, 6 (2017)

19. H. Huka, C. Ruoja, and A. Mchopa. Eur. J. Bus. Manag. 6, 36 (2014)

20. Susanawati, Jamhari, Masyhuri, and Dwidjono. Agrar. J. Agribus. Rural Dev. Res. 1, 1 (2015)

21. K. Mathusuthan and K. Sooriyakumar. Int. J. Environ. Agric. Res. 3, 8 (2017)

22. S. Suresh, A. Chaudhary, B. Mathur, and D. Gupta. Int. J. Adv. Res. Sci. Eng. 6, 2 (2017)

23. Suhaeni, S. A. Andayani, and Y. Sumekar. Int. J. Vet. Sci. Agric. Res. 1, 4 (2019)

24. S. Kar. Acta Sci. Agric. 4, 7 (2020)

25. K. M. M. Adnan, M. Rahman, and S. A. Sarker. Univers. J. Agric. Res. 2, 2 (2014)

26. Y. B. Imam, B. M. Chibok, and Y. Gamama. J. Biol. Agric. Healthc. 4, 22 (2014)

27. Q. T. Jassam, N. Ali, and A. S. Shukur. J. Agric. Vet. Sci. 11, 7 (2018)

28. R. H. Priyana, E. Tety, and Eliza. Jom Faperta. 2, 2 (2015)

29. R. Maysari. J. Galung Trop. 6, 3 (2017)

30. I. Annisa, R. W. Asmarantaka, and R. Nurmalina. J. Ilm. Manaj. 8, 2 (2018)

31. Badan Pusat Statistik Indonesia. (2018)

32. B. Wicaksena and Sahara. ASEAN J. Econ. Manag. Account. 1, 2 (2013)

33. T. Marwa, A. Bashir, Azwardi, M. Adam, and K. M. H. Thamrin. Int. J. Econ. Bus. Adm. V, 2 (2017)

34. R. Anindita, N. Baladina, and B. Setiawan. Russ. J. Agric. Socio-Economic Sci. 7, 19 (2013)

35. N. L. O. Ezealaji and K. O. Adenegan. Acad. Journals. 6, 3 (2014)

36. B. Kalita. Int. J. Adv. Res. Dev. 2, 8 (2017)

37. D. C. Lekatompessy, M. Turukay, and W. B. Parera. Agrilan. 5, 3 (2017)

38. V. K. Verma and S. Jheeba. Int. J. Seed Spices. 6, 1 (2016)

39. D. E. Pratiwi, B. Setiawan, C. Puspo, Nugroho, and A. E. Hardana. IOP Conf. Ser. Earth and Environ. Sci. 334 (2019) 